\title{
LIGNIN DEGRADATION, LIGNINOLYTIC ENZYMES ACTIVITIES AND EXOPOLYSACCHARIDE PRODUCTION BY GRIFOLA FRONDOSA STRAINS CULTIVATED ON OAK SAWDUST
}

\author{
Nona A. Mikiashvili; Omoanghe S. Isikhuemhen*; Elijah I. Ohimain
}

Mushroom Biology \& Fungal Biotechnology Laboratory, School of Agriculture and Environmental Sciences, North Carolina A\&T State University, Greensboro, NC 2741, USA.

Submitted: November 12, 2009; Returned to authors for corrections: January 04, 2011; Approved: March $14,2011$.

\begin{abstract}
Fourteen strains of Grifola frondosa (Dicks.) S. F. Gray, originating from different regions (Asia, Europe and North America) were tested for lignin degradation, ligninolytic enzyme activities, protein accumulation and exopolysaccharide production during 55 days of cultivation on oak sawdust. Lignin degradation varied from 2.6 to $7.1 \%$ of dry weight of the oak sawdust substrate among tested strains. The loss of dry matter in all screened fungi varied between 11.7 and $33.0 \%$, and the amount of crude protein in the dry substrate varied between 0.94 to $2.55 \%$. The strain, MBFBL 596, had the highest laccase activity (703.3 U/l), and the maximum peroxidase activity of $22.6 \mathrm{U} / \mathrm{l}$ was shown by the strain MBFBL 684 . Several tested strains (MBFBL 21, 638 and 662) appeared to be good producers of exopolysaccharides (3.5, 3.5 and $3.2 \mathrm{mg} / \mathrm{ml}$ respectively).
\end{abstract}

Key words: Grifola frondosa; exopolysaccharide; laccase; lignin degradation; peroxidase

\section{INTRODUCTION}

Grifola frondosa is a white-rot basidiomycete that produces a highly nutritious fruit body used as food in different parts of the world. It has also been reported to contain bioactive metabolites, which exhibit various medicinal properties such as antitumor, antiviral, antioxidant, antidiabetic, immunomodulation $(11,14,23,12,13)$. Different plant waste material has been used for the cultivation of G. frondosa (15). In commercial cultivation, sterilized hardwood sawdust of alder and poplar is often used (16). Chung (7) used sawdust and cotton seed composts, while Xing et al. (22) reported cultivation of this fungus on a substrate consisting of beech sawdust, wheat bran and corn meal.

G. frondosa secretes ligninolytic enzymes to degrade the lignocellulose substrate from which it obtains needed nutrients for its growth and development. Extracellular laccase activity was detectable in liquid cultures of $G$. frondosa during the early/middle stages of primary growth (22). Total peroxidase and manganese independent peroxidase were found in brewery waste substrates used in solid-state fermentation involving $G$. frondosa (18). Polysaccharides are secreted during G. frondosa cultivation in both liquid and solid substrates used for its cultivation $(3,24)$. 
G. frondosa is of huge economic importance as a result of its nutritional and medicinal properties. Favorable conditions for growing it exist in the southeastern United States, where oak sawdust is abundant. However, poor yields persist, despite huge supplementation. This situation calls for basic research into substrate degradation and utilization, as well as into how the strains originating from different regions may affect enzyme production and substrate utilization. Therefore, a total of 14 isolates of $G$. frondosa, originating from North America, Europe and Asia were studied for ligninolytic enzymatic activities, lignin degradation rates, and exopolysaccharide production during cultivation on un-supplemented oak sawdust.

\section{MATERIALS AND METHODS}

\section{Fungal strains and cultivation}

Fourteen strains of $G$. frondosa from the Mushroom Biology and Fungal Biotechnology Laboratory (MBFBL) culture collection at North Carolina A\&T State University were used in this study (Table 1). Stock cultures of selected isolates were maintained on potato-dextrose agar at $4^{\circ} \mathrm{C}$. The inocula were grown for seven days in $250 \mathrm{~mL}$ flask containing $100 \mathrm{~mL}$ basal medium (g/l): glucose $10 ; \mathrm{KH}_{2} \mathrm{PO}_{4} \quad 0.8 ; \mathrm{NH}_{4} \mathrm{NO}_{3} 2$; $\mathrm{Na}_{2} \mathrm{HPO}_{4}$ 0.4; $\mathrm{MgSO}_{4} \cdot 7 \mathrm{H}_{2} \mathrm{O} 0.5$ and yeast extract 2 (pH 6.0). Mycelia were homogenized in a laboratory Warring blender. Solid-state fermentation of oak sawdust with test fungi was conducted in $250 \mathrm{ml}$ Erlenmeyer flasks, containing $5 \mathrm{~g}$ milled sawdust, mixed with $20 \mathrm{ml}$ water. The substrate was inoculated with $2 \mathrm{~mL}$ homogenate (43-52 $\mathrm{mg}$ of mycelia dry weight) and incubated at $23-24^{\circ} \mathrm{C}$ in the dark. After $15,25,35,45$ and 55 days of cultivation, crude extract from the biomass were extracted with $40 \mathrm{ml}$ of sodium acetate buffer $(100 \mathrm{mM}, \mathrm{pH}$ 5.0) at $4^{\circ} \mathrm{C}$, for 2 hours. The extract was filtered through Whatman paper and was used for determining enzyme activities and exopolysaccharide content. The biomass was dried at $60^{\circ} \mathrm{C}$ until reaching a constant weight. Loss of organic matter was calculated as the percent difference in dry weight between the test substrate and the control (uninoculated substrate). The three replicate flasks per strain that contained samples of the dried substrate were then combined into one sample, milled, and analyzed to determine crude protein and lignin contents.

\section{Enzyme activity assays}

Laccase activity was determined by the rate of oxidation of ABTS (2,2'-azinobis(3- ethylbenzothiazoline-6-sulfonic acid)) as a substrate at $420 \mathrm{~nm}$. The reaction mixture $(1 \mathrm{ml})$ contained $50 \mathrm{mM}$ acetate buffer ( $\mathrm{pH} 3.8), 1 \mathrm{mM}$ ABTS, and $100 \mu \mathrm{l}$ of appropriately diluted culture filtrate (9). Peroxidase activity was assayed by the oxidation of Phenol Red (8). The 1 $\mathrm{ml}$ reaction volume contained $450 \mu \mathrm{l}$ sodium lactate-succinate

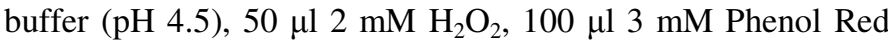
and $400 \mu \mathrm{l}$ diluted culture filtrate. The reactions were terminated by the addition of $100 \mu \mathrm{l} 2 \mathrm{M} \mathrm{NaOH}$ and absorbance was recorded at $610 \mathrm{~nm}$. One unit of enzyme activity was defined as the amount of enzyme that oxidized 1 $\mu$ mol substrate per minute.

\section{Lignin and crude protein assay}

Lignin components were analyzed by the Van Soest et al. (18) method for dietary fiber. The crude protein in the colonized sawdust substrate was determined by official methods of analysis (1). The conversion factor of total nitrogen to protein in the mushroom samples was 4.38 (4). The above mentioned analyses were conducted at the certified Rumen Fermentation Profiling Lab, West Virginia University, WV.

\section{Exopolysaccharides assay}

To measure levels of exopolysaccharides, 1 volume of culture extract (separated from the biomass) was mixed with 4 volumes of absolute ethanol, stirred and left for 24 hours at $4^{\circ} \mathrm{C}$. Precipitated polysaccharides were collected by centrifugation at $6000 \mathrm{~g}$ for $20 \mathrm{~min}$, dried at $60^{\circ} \mathrm{C}$ and weighed. 


\section{Statistical analysis}

SPSS software version 11 (Lead Technologies Inc. 2001) was used to carry out statistical analysis. A one-way analysis of variance was carried out at $\alpha=0.05$, and Duncan's multiple range test was used to compare the enzyme activities, polysaccharide production and biomass utilization among the fourteen tested strains.

\section{RESULTS AND DISCUSSION}

Results of the substrate utilization as measured by dry matter (biomass) loss revealed that most of the G. frondosa strains have weak abilities to utilize oak sawdust (Fig. 1). For most of the strains, dry matter decreased steadily between days 25 through day 55 of cultivation. However, the Asian strains (MBFBL 660, 684 and 662) and European strains (MBFBL
637, 638 and 649) showed a significant decrease in substrate weight much earlier (at day 15) during the cultivation period. MBFBL 662, 21 and 34 were found to be the best performing strains in terms of substrate utilization, and were associated with 1.3 - 1.5 times dry matter loss, compared to the control (Table 1). The Asian strains (MBFBL 660 and 684) and Northeast USA strains (MBFBL 598 and 605) produced the lowest rate of substrate utilization. Statistical analysis of dry matter loss results revealed significant differences $(P<0.05)$ among strains tested (not shown in Fig.1). Our findings are consistent with the report of Chen et al. (6), who observed differences among $G$. frondosa strains in biological and physiological characteristics, with different strains showing different mycelia colonization rates on agar plates and in solidstate fermentation in flasks.

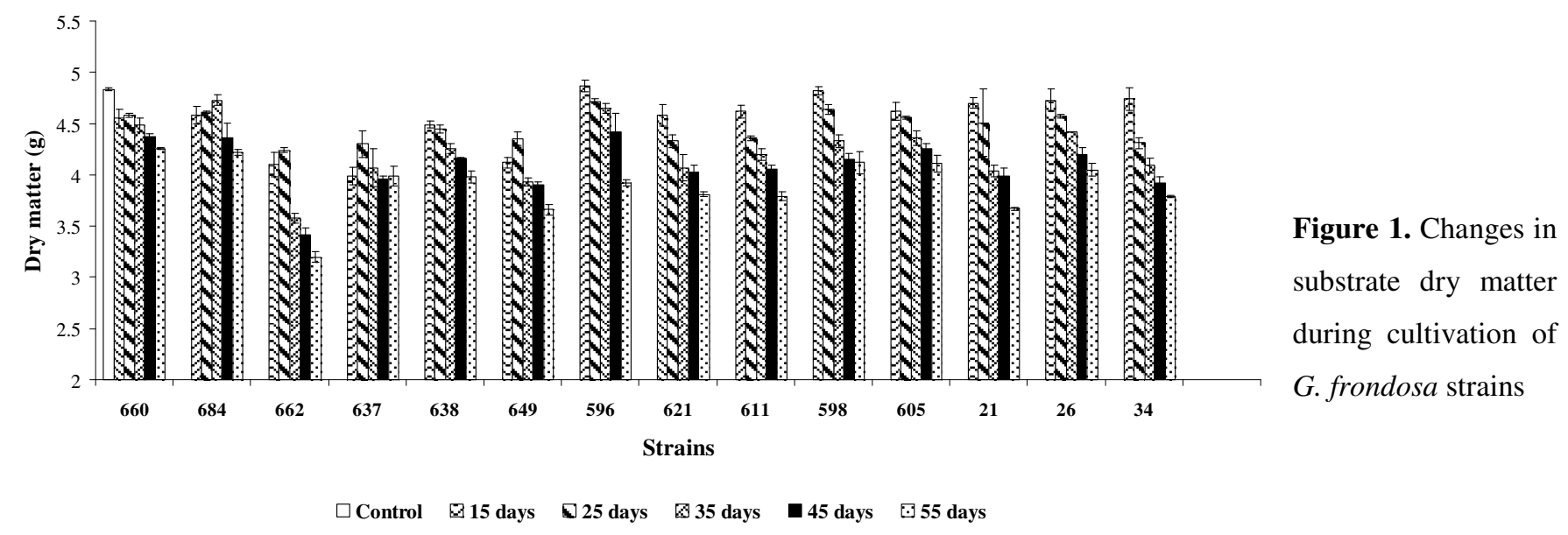

Table 1. Dry matter loss and lignin content in oak wood sawdust subtrate after cultivation with Grifola frondosa

\begin{tabular}{|c|c|c|c|}
\hline Region of origin & Strain ID & Loss of dry matter & Loss of lignin \\
\hline \multirow{3}{*}{ Asia } & MBFBL 660 & 10.8 & 2.6 \\
\hline & MBFBL 684 & 11.7 & 2.8 \\
\hline & MBFBL 662 & 33.0 & 7.1 \\
\hline \multirow[t]{3}{*}{ Europe } & MBFBL 637 & 17.5 & 3.2 \\
\hline & MBFBL 638 & 16.8 & 3.7 \\
\hline & MBFBL 649 & 23.4 & 4.4 \\
\hline \multirow[t]{3}{*}{ Northwest USA } & MBFBL 596 & 18.0 & 3.8 \\
\hline & MBFBL 621 & 20.4 & 3.8 \\
\hline & MBFBL 611 & 20.6 & 4.1 \\
\hline \multirow[t]{2}{*}{ Northeast USA } & MBFBL 598 & 13.7 & 5.3 \\
\hline & MBFBL 605 & 13.9 & 5.3 \\
\hline \multirow[t]{2}{*}{ North Carolina (USA) } & MBFBL 21 & 23.2 & 4.8 \\
\hline & MBFBL 26 & 15.3 & 4.4 \\
\hline Results are presented as $c$ & WABEFL 34 & 20.6 & 6.0 \\
\hline
\end{tabular}


The lignin content in the uninoculated substrate was $16.4 \%$. At the end of 55 days, the lignin loss ranged from 2.6 to $7.1 \%$ (Table 1). The lignin degradation during the first 25 days was low compared to the values obtained after 35 days of cultivation (Fig. 2). The Asian strain, MBFBL 662, showed the highest lignin degradation rate $(7.1 \%)$, followed by the North East USA strains (MBFBL 598, 605). Arora and Sandhu (2) reported an angiospermic wood sawdust total weight loss of $6 \%$ accompanied by a $14 \%$ lignin loss during 60 days of incubation with Pleurotus ostreatus.

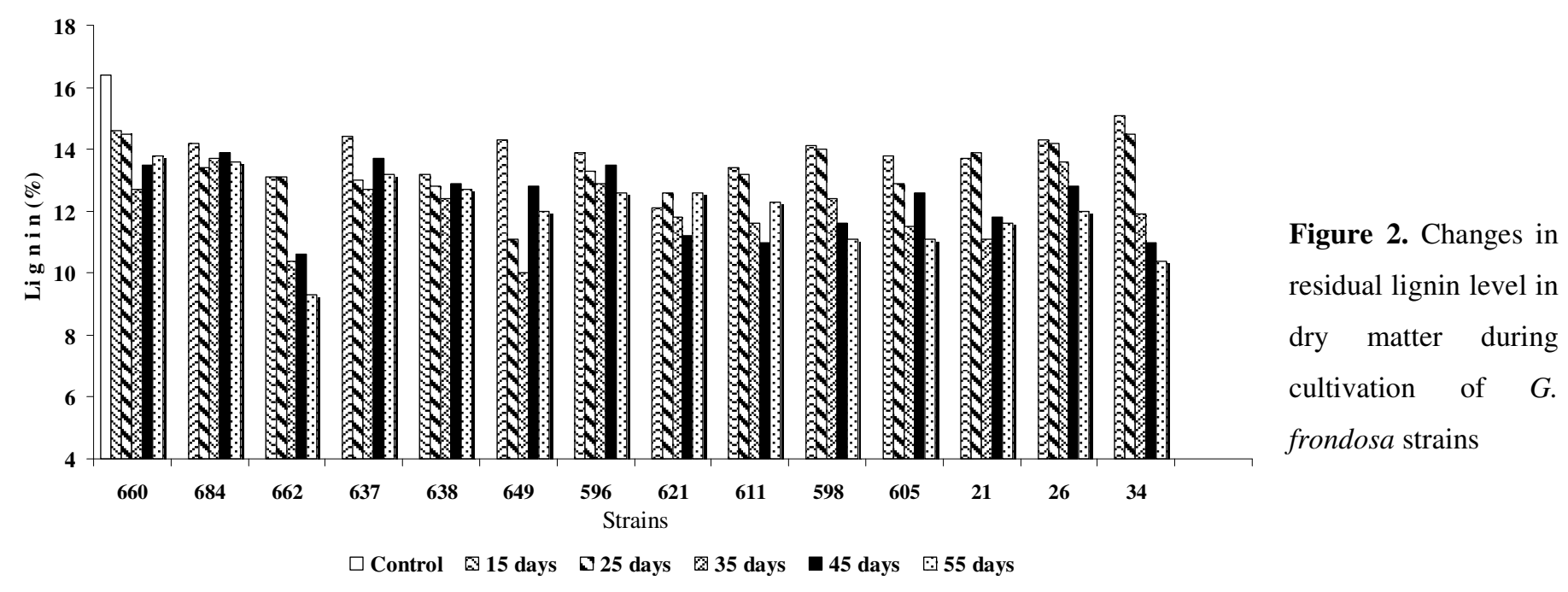

Total protein content varied between strains and length of cultivation (Table 2). After 55 days, crude protein content in the substrates increased from $1.48 \%$ in the uninoculated substrate to values ranging from 1.85 to $2.55 \%$. Asian strains showed the highest protein accumulation, ranging from 1.98 -
2.55\%. Northwest USA strains also showed comparatively high protein content $(2.21-2.37 \%)$. Tabata et al. (19) reported a $1.66 \%$ substrate protein accumulation during fructification of G. frondosa in rice bran supplemented sawdust.

Table 2. Crude protein accumulation in dry matter during cultivation of $G$. frondosa species

\begin{tabular}{|c|c|c|c|c|c|}
\hline Strains & 10 days & 25 days & 35 days & 45 days & 55 days \\
\hline MBFBL 660 & 1.58 & 2.08 & 1.97 & 1.97 & 2.11 \\
\hline MBFBL 684 & 1.27 & 0.94 & 1.12 & 1.50 & 1.98 \\
\hline MBFBL 662 & 1.72 & 1.89 & 2.30 & 2.42 & 2.55 \\
\hline MBFBL 637 & 1.66 & 1.70 & 1.75 & 1.81 & 1.94 \\
\hline MBFBL 638 & 1.63 & 2.03 & 1.96 & 1.94 & 2.00 \\
\hline MBFBL 649 & 1.96 & 1.98 & 2.19 & 2.18 & 2.48 \\
\hline MBFBL 596 & 1.35 & 1.37 & 1.75 & 2.01 & 2.21 \\
\hline MBFBL 621 & 1.70 & 1.77 & 2.15 & 2.06 & 2.25 \\
\hline MBFBL 611 & 1.74 & 1.80 & 2.21 & 2.03 & 2.37 \\
\hline MBFBL 598 & 1.51 & 1.92 & 1.69 & 1.99 & 1.91 \\
\hline MBFBL 605 & 1.49 & 1.61 & 2.05 & 2.09 & 1.85 \\
\hline MBFBL 21 & 1.72 & 1.69 & 2.17 & 1.97 & 2.08 \\
\hline MBFBL 26 & 1.35 & 1.74 & 2.11 & 2.21 & 1.92 \\
\hline MBFBL 34 & 1.82 & 2.25 & 2.09 & 2.20 & 2.40 \\
\hline
\end{tabular}

Results are presented as \% of substrate dry weight

Uninoculated substrate consists of $1.48 \%$ crude protein 
The data on ligninolytic enzyme activities (Table 3 and 4) shows that all strains produced the highest amount of laccase enzyme on day 15 . The strong correlation (0.817), between substrate utilization and laccase activity was obtained only on strain MBFBL 21. The highest laccase activity (703.3 U/l) was recorded for the G. frondosa strain MBFBL 596, and the lowest activities were in MBFBL 598 and 605 strains, 13.2 and $10.7 \mathrm{U} / \mathrm{l}$, respectively. Xing et al. (22) showed that during liquid cultivation of $G$. frondosa, laccase activity reached a maximum value of 70 U/l after 52 days. Vikineswary et al. (21) observed degradation of rubberwood sawdust by Pycnoporus sanguineus, where maximal laccase productivity reached $5.7 \mathrm{U} / \mathrm{g}$ on day 11 .

Table 3. Laccase activities among $G$. frondosa strains during 55 days of cultivation

\begin{tabular}{lccccc}
\hline Strains & 15 days & 25 days & 35 days & 45 days & 55 days \\
\hline MBFBL 660 & $50.06 \pm 1.98 \mathrm{~d}$ & $29.81 \pm 1.27 \mathrm{cde}$ & $5.92 \pm 0.46 \mathrm{abc}$ & $5.46 \pm 0.79 \mathrm{bcd}$ & $3.64 \pm 0.91 \mathrm{~cd}$ \\
MBFBL 684 & $38.46 \pm 1.78 \mathrm{c}$ & $34.36 \pm 2.17 \mathrm{de}$ & $36.41 \pm 2.41 \mathrm{~d}$ & $15.02 \pm 1.58 \mathrm{e}$ & $10.92 \pm 0.79 \mathrm{e}$ \\
MBFBL 662 & $44.60 \pm 1.38 \mathrm{~cd}$ & $54.15 \pm 2.41 \mathrm{f}$ & $6.37 \pm 0.46 \mathrm{abc}$ & $17.29 \pm 0.91 \mathrm{e}$ & $5.01 \pm 0.45 \mathrm{~d}$ \\
MBFBL 637 & $6.37 \pm 0.60 \mathrm{a}$ & $30.94 \pm 1.20 \mathrm{cde}$ & $3.19 \pm 0.91 \mathrm{ab}$ & $2.28 \pm 0.91 \mathrm{ab}$ & $1.82 \pm 0.91 \mathrm{abc}$ \\
MBFBL 638 & $14.56 \pm 0.99 \mathrm{ab}$ & $19.79 \pm 1.04 \mathrm{abc}$ & $6.37 \pm 0.46 \mathrm{abc}$ & $8.19 \pm 0.79 \mathrm{~d}$ & $3.64 \pm 0.46 \mathrm{~cd}$ \\
MBFBL 649 & $10.47 \pm 0.60 \mathrm{ab}$ & $38.23 \pm 1.81 \mathrm{e}$ & $6.83 \pm 0.79 \mathrm{abc}$ & $3.64 \pm 0.46 \mathrm{abc}$ & $2.73 \pm 0.79 \mathrm{bc}$ \\
MBFBL 596 & $703.30 \pm 12.43 \mathrm{e}$ & $688.52 \pm 12.32 \mathrm{~g}$ & $145.17 \pm 4.04 \mathrm{e}$ & $52.33 \pm 3.28 \mathrm{f}$ & $0.91 \pm 0.46 \mathrm{ab}$ \\
MBFBL 621 & $11.60 \pm 0.79 \mathrm{ab}$ & $31.85 \pm 2.77 \mathrm{de}$ & $4.55 \pm 1.98 \mathrm{abc}$ & $4.55 \pm 0.45 \mathrm{abd}$ & $2.73 \pm 0.79 \mathrm{bc}$ \\
MBFBL 611 & $21.39 \pm 1.21 \mathrm{~b}$ & $8.19 \pm 0.39 \mathrm{a}$ & $2.28 \pm 0.45 \mathrm{a}$ & $1.82 \pm 0.45 \mathrm{ab}$ & 0 \\
MBFBL 598 & $11.38 \pm 0.82 \mathrm{ab}$ & $13.20 \pm 1.21 \mathrm{ab}$ & $8.42 \pm 0.60 \mathrm{c}$ & $6.83 \pm 1.37 \mathrm{~cd}$ & $0.46 \pm 0.46 \mathrm{a}$ \\
MBFBL 605 & $5.01 \pm 0.23 \mathrm{a}$ & $10.69 \pm 0.60 \mathrm{a}$ & $1.82 \pm 0.45 \mathrm{a}$ & $0.91 \pm 0.46 \mathrm{a}$ & 0 \\
MBFBL 21 & $16.38 \pm 0.79 \mathrm{ab}$ & $10.24 \pm 0.79 \mathrm{a}$ & $9.10 \pm 0.46 \mathrm{c}$ & $7.28 \pm 0.45 \mathrm{~cd}$ & $2.73 \pm 0.79 \mathrm{bc}$ \\
MBFBL 26 & $12.52 \pm 1.38 \mathrm{ab}$ & $23.89 \pm 1.18 \mathrm{bcd}$ & $7.74 \pm 1.98 \mathrm{bc}$ & $2.28 \pm 0.45 \mathrm{ab}$ & 0 \\
MBFBL 34 & $18.20 \pm 0.60 \mathrm{~b}$ & $9.56 \pm 0.79 \mathrm{a}$ & $3.19 \pm 0.46 \mathrm{ab}$ & $7.74 \pm 0.45 \mathrm{~d}$ & 0 \\
\hline
\end{tabular}

Results of laccase activities are presented in U/l

Each value is expressed as mean $\pm \operatorname{SD}(n=3)$

Different letters in each column indicate significant differences at $P<0.05$

Table 4. Peroxidase activities in G. frondosa strains during 55 days of cultivation

\begin{tabular}{cccccc}
\hline Strains & $\mathbf{1 5}$ days & $\mathbf{2 5}$ days & 35 days & 45 days & $\mathbf{5 5}$ days \\
\hline MBFBL 660 & $5.45 \pm 0.55 \mathrm{~d}$ & $6.67 \pm 0.28 \mathrm{~g}$ & $3.03 \pm 0.21 \mathrm{a}$ & $4.00 \pm 0.73 \mathrm{a}$ & $6.55 \pm 0.36 \mathrm{bc}$ \\
MBFBL 684 & $7.00 \pm 0.72 \mathrm{e}$ & $8.67 \pm 0.76 \mathrm{~h}$ & $22.55 \pm 0.55 \mathrm{~h}$ & $9.82 \pm 0.63 \mathrm{e}$ & $8.36 \pm 0.36 \mathrm{de}$ \\
MBFBL 662 & $5.39 \pm 0.56 \mathrm{~d}$ & $6.61 \pm 0.46 \mathrm{~g}$ & $7.45 \pm 0.18 \mathrm{f}$ & $15.18 \pm 0.91 \mathrm{e}$ & $10.06 \pm 0.42 \mathrm{f}$ \\
MBFBL 637 & $3.76 \pm 0.37 \mathrm{bc}$ & $5.58 \pm 0.38 \mathrm{de}$ & $5.09 \pm 0.48 \mathrm{cde}$ & $8.97 \pm 0.56 \mathrm{de}$ & $7.52 \pm 0.76 \mathrm{~cd}$ \\
MBFBL 638 & $3.27 \pm 0.33 \mathrm{~b}$ & $4.18 \pm 0.18 \mathrm{ab}$ & $3.33 \pm 0.10 \mathrm{a}$ & $4.97 \pm 0.21 \mathrm{a}$ & $6.79 \pm 1.87 \mathrm{bc}$ \\
MBFBL 649 & $4.21 \pm 0.41 \mathrm{c}$ & $5.21 \pm 0.10 \mathrm{fg}$ & $5.88 \pm 0.28 \mathrm{de}$ & $7.03 \pm 0.56 \mathrm{e}$ & $13.33 \pm 0.56 \mathrm{~g}$ \\
MBFBL 596 & $4.15 \pm 0.19 \mathrm{c}$ & $6.36 \pm 0.18 \mathrm{cde}$ & $3.88 \pm 0.46 \mathrm{ab}$ & $9.70 \pm 0.56 \mathrm{bc}$ & $5.70 \pm 0.56 \mathrm{~b}$ \\
MBFBL 621 & $2.36 \pm 0.09 \mathrm{a}$ & $4.79 \pm 0.28 \mathrm{bc}$ & $5.45 \pm 0.48 \mathrm{cde}$ & $6.79 \pm 0.56 \mathrm{~b}$ & $7.15 \pm 0.56 \mathrm{~cd}$ \\
MBFBL 611 & $3.64 \pm 0.24 \mathrm{bc}$ & $5.27 \pm 0.09 \mathrm{i}$ & $3.58 \pm 0.46 \mathrm{a}$ & $7.39 \pm 1.11 \mathrm{bc}$ & $4.36 \pm 0.63 \mathrm{a}$ \\
MBFBL 598 & $2.39 \pm 0.14 \mathrm{a}$ & $3.76 \pm 0.38 \mathrm{a}$ & $6.00 \pm 0.48 \mathrm{e}$ & $4.12 \pm 0.56 \mathrm{a}$ & $6.42 \pm 0.56 \mathrm{bc}$ \\
MBFBL 605 & $2.61 \pm 0.19 \mathrm{a}$ & $6.24 \pm 0.28 \mathrm{fg}$ & $5.03 \pm 0.28 \mathrm{~cd}$ & $7.39 \pm 0.21 \mathrm{bc}$ & $9.33 \pm 0.42 \mathrm{ef}$ \\
MBFBL 21 & $4.85 \pm 0.46 \mathrm{~d}$ & $4.97 \pm 0.21 \mathrm{~cd}$ & $5.82 \pm 0.58 \mathrm{~g}$ & $10.06 \pm 0.76 \mathrm{e}$ & $7.03 \pm 0.92 \mathrm{bcd}$ \\
MBFBL 26 & $3.36 \pm 0.18 \mathrm{~b}$ & $5.88 \pm 0.46 \mathrm{ef}$ & $4.67 \pm 0.21 \mathrm{bc}$ & $6.42 \pm 0.56 \mathrm{~b}$ & $9.45 \pm 0.73 \mathrm{ef}$ \\
MBFBL 34 & $2.33 \pm 0.10 \mathrm{a}$ & $5.45 \pm 0.48 \mathrm{cde}$ & $5.45 \pm 0.48 \mathrm{cde}$ & $8.00 \pm 0.96 \mathrm{~cd}$ & $5.70 \pm 0.42 \mathrm{~b}$ \\
\hline
\end{tabular}

Results of peroxidase activities are presented in $\mathrm{U} / 1$

Each value is expressed as mean $\pm \operatorname{SD}(n=3)$

Different letters in each column indicate significant differences at $P<0.05$ 
Among the strains, MBFBL 684 appeared to be the best producer of peroxidase $(22.6 \mathrm{U} / \mathrm{l})$ at 35 days. Mn-Peroxisade activity, though measured, showed insignificant activity in strains tested (data not shown). The correlation between substrate utilization and peroxidase activities was poor, and the relationship between substrate utilization and enzyme activities is not linear. Kadimaliev et al. (10) observed considerably lower laccase activity during 14 days of growing Lentinus tigrinus on pine sawdust $(2.3 \mathrm{U} / \mathrm{g})$ compared to birch sawdust $(20 \mathrm{U} / \mathrm{g})$, while peroxidase activity measured by $o$-dianisidine ranged from 0.6 and $0.65 \mathrm{U} / \mathrm{g}$ on birch and pine sawdust, respectively.

G. frondosa MBFBL 21 and 662 produced the highest yields exopolysaccharides $(3.5$ and $3.2 \mathrm{mg} / \mathrm{ml})$ on day 45 of cultivation (Table 5). A positive correlation between dry matter loss and polysaccharide secretion was obtained only in MBFBL 26. Zhou et al. (24) showed a $3.81 \mathrm{mg} / \mathrm{ml}$ exopolysaccharide accumulation by $G$. frondosa mycelium in a sucrose-brain medium. Bae et al. (3), obtained $7.2 \mathrm{mg} / \mathrm{ml}$ exopolysaccharide on day 4 during cultivation of $G$. frondosa in a fermenter.

Table 5. Polysaccharides secretion in G. frondosa strains during cultivation on oak wood sawdust

\begin{tabular}{lccccc}
\hline Strains & 15 days & 25 days & 35 days & 45 days & 55 days \\
\hline MBFBL 660 & $1.00 \pm 0.10 \mathrm{c}$ & $1.23 \pm 0.06 \mathrm{e}$ & $0.87 \pm 0.06 \mathrm{bcd}$ & $1.77 \pm 0.15 \mathrm{ab}$ & $1.13 \pm 0.06 \mathrm{ab}$ \\
MBFBL 684 & $0.93 \pm 0.06 \mathrm{c}$ & $1.27 \pm 0.06 \mathrm{e}$ & $1.00 \pm 0.10 \mathrm{cde}$ & $0.87 \pm 0.06 \mathrm{ab}$ & $1.70 \pm 0.10 \mathrm{e}$ \\
MBFBL 662 & $1.30 \pm 0.00 \mathrm{de}$ & $1.10 \pm 0.10 \mathrm{de}$ & $1.47 \pm 0.06 \mathrm{~g}$ & $3.23 \pm 0.15$ & $3.00 \pm 0.60 \mathrm{f}$ \\
MBFBL 637 & $1.23 \pm 0.06 \mathrm{de}$ & $0.53 \pm 0.23 \mathrm{a}$ & $0.93 \pm 0.06 \mathrm{bcd}$ & $1.77 \pm 0.15 \mathrm{ab}$ & $0.83 \pm 0.06 \mathrm{a}$ \\
MBFBL 638 & $0.97 \pm 0.06 \mathrm{c}$ & $0.80 \pm 0.10 \mathrm{bc}$ & $1.23 \pm 0.15 \mathrm{f}$ & $2.17 \pm 0.06 \mathrm{ab}$ & $1.47 \pm 0.12 \mathrm{bcde}$ \\
MBFBL 649 & $1.50 \pm 0.10 \mathrm{e}$ & $0.93 \pm 0.15 \mathrm{bcd}$ & $0.40 \pm 0.10 \mathrm{a}$ & $2.37 \pm 0.06 \mathrm{ab}$ & $1.20 \pm 0.26 \mathrm{bc}$ \\
MBFBL 596 & $0.23 \pm 0.06 \mathrm{a}$ & $2.83 \pm 0.12 \mathrm{f}$ & $1.43 \pm 0.15 \mathrm{~g}$ & $2.67 \pm 0.15 \mathrm{ab}$ & $1.67 \pm 0.06 \mathrm{de}$ \\
MBFBL 621 & $2.23 \pm 0.64 \mathrm{f}$ & $0.53 \pm 0.15 \mathrm{a}$ & $1.17 \pm 0.06 \mathrm{ef}$ & $1.67 \pm 0.15 \mathrm{ab}$ & $1.30 \pm 0.10 \mathrm{bcd}$ \\
MBFBL 611 & $0.70 \pm 0.10 \mathrm{bc}$ & $2.83 \pm 0.15 \mathrm{f}$ & $1.73 \pm 0.15 \mathrm{~h}$ & $2.90 \pm 0.10 \mathrm{ab}$ & $1.33 \pm 0.06 \mathrm{bcde}$ \\
MBFBL 598 & $2.67 \pm 0.12 \mathrm{~g}$ & $0.83 \pm 0.06 \mathrm{bc}$ & $1.03 \pm 0.06 \mathrm{de}$ & $1.53 \pm 0.06 \mathrm{ab}$ & $1.33 \pm 0.06 \mathrm{bcde}$ \\
MBFBL 605 & $1.07 \pm 0.06 \mathrm{~cd}$ & $1.00 \pm 0.10 \mathrm{~cd}$ & $0.83 \pm 0.12 \mathrm{bc}$ & $2.93 \pm 0.15 \mathrm{~b}$ & $1.50 \pm 0.10 \mathrm{bcde}$ \\
MBFBL 21 & $0.43 \pm 0.06 \mathrm{ab}$ & $3.10 \pm 0.10 \mathrm{~g}$ & $1.90 \pm 0.10 \mathrm{~h}$ & $3.50 \pm 3.90 \mathrm{~b}$ & $1.57 \pm 0.15 \mathrm{cde}$ \\
MBFBL 26 & $0.97 \pm 0.06 \mathrm{c}$ & $0.77 \pm 0.06 \mathrm{~b}$ & $1.13 \pm 0.12 \mathrm{ef}$ & $1.97 \pm 0.21 \mathrm{ab}$ & $1.43 \pm 0.06 \mathrm{bcde}$ \\
MBFBL 34 & $1.53 \pm 0.25 \mathrm{e}$ & $0.90 \pm 0.10 \mathrm{bcd}$ & $0.80 \pm 0.10 \mathrm{~b}$ & $1.50 \pm 0.10 \mathrm{ab}$ & $1.67 \pm 0.15 \mathrm{de}$ \\
\hline
\end{tabular}

Results of polisaccharides presented in $\mathrm{mg} / \mathrm{ml}$

Each value is expressed as mean $\pm S D(n=3)$

Different letters in each column indicate significant differences at $P<0.05$

It appears that $G$. frondosa is not as hardy a lignin degrader as Pleurotus spp, Lentinula edodes, Phanerochaete chrysosporium and Ganoderma colossum, which have been reported to have lignin degradation of $14 \%$ on angiospermic wood sawdust (2), 39-60\% on Eucalyptus sawdust (5), 12\% on red oak and $16.7 \%$ on white fir (15), respectively. It fruits off living roots of trees as a weak parasite, which does not kill its host quickly (http://botit.botany.wisc.edu/toms_fungi/nov2006. html). From a particular tree in Greensboro NC where $G$. frondosa has been collected continuously for 5 years, each time the fruit body is picked up, latex was seen oozing from the point of collection of the $G$. frondosa fruit body from the oak tree root. It is possible that the photosynthetic system of their host (live oak trees) is exploited, in addition to minimal substrate degradation, to acquire the nutrients that the fungus needs to make fruit bodies in nature; that might explain the relative difficulty in cultivation of this fungus for fruit body production. 
The results showed that ligninolytic enzymes production, sawdust substrate degradation and exopolysaccharide production appears to be strain specific and not affected by the origin of strains tested. In general, G. frondosa seems to be a weak degrader of sawdust, although it is found associated with oak trees in the wild. Our results have helped us to detect strains that seem to be the best oak substrate degraders, which we are now applying in mass production studies, polysaccharide secretion and breeding to obtain improved strains needed for other biotechnological applications.

\section{ACKNOWLEDGEMENTS}

Research was supported Evans-Allen funding through the USDA-CSREES, 1400 Independence Ave., S.W. Washington DC. We are thankful for the technical review by the Agricultural Research Program and editorial review received from Laurie Gengenbach in Ag. Communication, School of Agriculture and Environmental Science, North Carolina A\&T State University.

\section{REFERENCES}

1. AOAC. (1990). Official Methods of Analysis. Association of Official Analytical Chemists. $15^{\text {th }}$ Edition, AOAC International Gaithersburg, Maryland.

2. Arora, D.S.; Sandhu, D.K. (1987). Decomposition of angiospermic wood sawdust and laccase production by two Pleurotus species. J. Basic Microbiol. 27, 179-184.

3. Bae, J.T.; Sim, G.S.; Lee, D.H.; Lee, B.C.; Pyo, H.B.; Choe, B.T.; Yun, J.W. (2005). Production of exopolysaccharide from mycelial culture of Grifola frondosa and its inhibitory effect on matrix metalloproteinase-1 expression in UV-irradiated human dermal fibroblasts. FEMS Microb. Lett. 251, 347-354.

4. Braaksma, A.; Schaap, D.J. (1996). Protein analysis of the common mushroom Agaricus bisporus. Postharvest Biology and Technology 7 , 119-127.

5. Brienzo, M.; Silva, E.; Milagres, A. (2007). Degradation of eucalypt waste components by Lentinula edodes strains detected by chemical and near-infrared spectroscopy methods. Appl. Biochem. Biotechnol. 141, $37-49$.
6. Chen, A.W.; Stamets, P.; Huang, N.L.; Han, S.H. (1999). Maitake at a Glance. The Mushroom Growers' Newsletter. Available at: http://www.mushroomcompany.com/resources/maitake/ataglance.pdf. Accessed 05 January, 2011.

7. Chung, S.T. (2005). Witnessing the development of the mushroom industry in China. In Tan Q, Zhang, JS, Chen MJ, Cao H, Buswell JA, (eds). Proceedings of the Fifth International Conference on Mushroom Biology and Mushroom Products, Shanghai, pp. 3-19.

8. Glenn, J.K.; Gold, M.H. (1985). Purification and characterization of an extracellular $\mathrm{Mn}(\mathrm{II})$-dependent peroxidase from the lignin degrading basidiomycete Phanerochaete chrysosporium. Arch. Biochem. Biophys. 242, 329-341.

9. Isikhuemhen, O.S.; Nerud, F. (1999). Preliminary studies on the ligninolytic enzymes produced by the tropical fungus Pleurotus tuberregium (Fr.) Sing. Antonie Van Leeuwenhoek 75, 257-260.

10. Kadimarev, D.A.; Revin, V.V.; Atykyan, N.A.; Samuilov, V.D. (2003). Effect of wood modification of lignin consumption and synthesis of lignolytic enzymes by the fungus Panus (lentinus) tigrinus. Appl. Biochem. Microbiol. 39, 488-492.

11. Kodama, N.; Komuta, M.D.; Nanba, H. (2002). Maitake MD-Fraction aid cancer patients? Altern. Med. Rev. 7 (3), 236-239.

12. Kubo, K.; Aoki, H.; Nanba, H. (1994). Anti-diabetic activity present in the fruit body of Grifola frondosa (Maitake). Biol. Pharmaceutical Bulletin 17, 106-1110.

13. Minato, K.I.; Mizuni, M.; Sachiko, K.; Tatsuoka, S.; Denpo, Y.; Tokimoro, K.; Tsuchida, H. (2001). Changes in immunomodulating activities and content of antitumor polisacharides during the growth of two medicinal mushrooms, Lentinus edodes (Berk.) Sing. and Grifola frondosa (Dicks.:Fr.) S.F. Gray. Intern. J. Med. Mushr. 3, 1-7.

14. Nanba, H.; Kodama, N.; Schar, D.; Turner, D. (1999). Maitake (Grifola frondosa) can maintain the health of people suffering with HIV infection? Third International Conference on Mushroom Biology and Mushroom Products, Sydney, Australia, pp. 194-198.

15. Oriaran, T.P.; Labosky, P.; Royse, D.J. (1989). Lignin Degradation Capabilities of Pleurotus ostreatus, Lentinula edodes and Phanerochaete chrysosporium. Wood and Fiber Science 21, 183-192.

16. Stamelts, P. (2000). Growing Gourmet and Medicinal Mushrooms, Ten Speed Press, Toronto.

17. Stott, K.; Mohamed, C. (2003). Cultivation of the edible and medicinal mushroom Grifola frondosa (Dicks.:Fr.) S.F. Gray (Maitake) - relevance of literature to production in Australia (Review). Inter. J. Med. Mush. 5, 199-216.

18. Svagei, M.; Berovich, M.; Gregori, A.; Pahor, B.; Pohleven. F. (2007). Production of Grifola frondosa enzymes on solid-state brewery industry wastes. J. Biotech. 131 (2) Supplement 1, S211-S241.

19. Tabata, T.; Yamasak, Y.; Ogura, T. (2004). Comparison of Chemical Compositions of Maitake (Grifola frondosa (Fr.) S. F. Gray) Cultivated 
on Logs and Sawdust Substrate. Food Sci. Technol. Res. 10, 21-24.

20. Van Soest, P.J.; Pobertson, J.B.; Lewis, B.A. (1991). Methods for dietary fiber, neutral detergent fiber and nonstarch polysaccharides in relation to animal nutrition. J. Dairy Sci. 74, 3583-3597.

21. Vikineswary, S.; Abdullah, N.; Renuvathani, M.; Sekaran, M.; Pandey, A.; Jones, E.B.G. (2006). Productivity of laccase in solid substrate fermentation of selected agro-residues by Pycnoporus sanguineus. Biore. Technol. 97, 171-177.

22. Xing, Z.T.; Cheng, J.H.; Tan, Q.; Pan, Y.J. (2006). Effect of nutritional parameters on laccase production by the culinary and medicinal mushroom, Grifola frondosa. World J. Microbiol. Biotech 22, 799-806

23. Zhang, Y.; Mills, G.L.; Nair, M.G. (2002). Cyclooxygenase inhibitory and antioxidant compounds from the mycelia of the edible mushroom Grifola frondosa. J. Agric. Food Chem. 50 (26), 7581-7585

24. Zhou, C.; Guo, Q.; Yang, Y.A. (2001). Study of the submerged fermentation of the mycelium of the medicinal mushroom Grifola frondosa (Dicks.: Fr.) S. F. Gray. Inter. J. Med. Mush. 3, 252. 